\title{
KNOWLEDGE SPILLOVERS THROUGH INTERNATIONAL SUPPLY CHAINS ${ }^{\mathrm{a}}$
}

\section{Roberta Piermartini ${ }^{\mathrm{b}}$ and Stela Rubínovác}

\begin{abstract}
$\underline{\text { Abstract }}$
Using industry-level R\&D and patent data for a sample of 29 countries for the period 2000-2008, we study the importance of international supply linkages for knowledge spillovers. We find a statistically significant effect of supply chains on international knowledge spillovers and show that knowledge spillovers increase with the intensity of supply chains linkages between countries. We also show that the evidence that knowledge spillovers flow along the supply chains is more robust than the traditional finding that knowledge spillovers depend on geographical distance or trade flows. This finding supports policies that favour participation in supply chains to foster economic development.
\end{abstract}

\footnotetext{
a The authors thank Richard Baldwin, Nicolas Berman, Cosimo Beverelli, Christian Henn, Wolfgang Keller, Antony Taubman, Jayashree Watal, Yoto Yotov and the participants of the GTDW for their useful comments. This is a working paper, and hence it represents research in progress. Stela Rubínová gratefully acknowledges the support of ProDoc Training Module: PDAMP1 $\_135828$. This paper represents the opinions of the authors, and is the product of professional research. It is not meant to represent the position or opinions of the WTO or its Members, nor the official position of any staff members. Any errors are the fault of the authors.

${ }^{\mathrm{b}}$ Senior Economist at the Research Division of the World Trade Organization. E-mail: roberta.piermartini@wto.org.

${ }^{\mathrm{c}}$ Graduate Institute of International and Development Studies, Geneva. E-mail: stela.rubinova@iheid.ch.

(C) The Authors.
}

All rights reserved. No part of this publication may be reproduced without the permission of the authors. $\underline{\text { http://graduateinstitute.ch/ctei }}$ 


\section{CENTRE For TRADE AND ECONOMIC INTEGRATION (CTEI)}

The Centre for Trade and Economic Integration fosters world-class multidisciplinary scholarship aimed at developing solutions to problems facing the international trade system and economic integration more generally. It works in association with public sector and private sector actors, giving special prominence to Geneva-based International Organisations such as the WTO and UNCTAD. The Centre also bridges gaps between the scholarly and policymaking communities through outreach and training activities in Geneva.

$\underline{\text { www.graduateinstitute.ch/ctei }}$ 


\section{Introduction}

It is often argued that international supply chains can be a powerful channel for technology transfer. They involve trade in goods, intermediate inputs, foreign direct investment and movement of key personnel. Therefore, they provide access to knowledge embodied in goods produced abroad, as well as to organizational and managerial know-how.

One argument is that knowledge flows easily within supply chains because outsourcing firms are more willing to transfer knowledge. Within a supply chain, the firm outsourcing an input has an incentive to transfer the technology required for its efficient production because it will eventually be the consumer of that input and needs to assure compatibility with its own production process. As Baldwin and Lopez-Gonzalez (2013) states "When Toyota makes car parts in Thailand, they do not rely on local know-how; they bring Toyota technology, Toyota management, Toyota logistics and any other bits of know-how needed since the Thai-made parts have to fit seamlessly into the company's production network."

Another argument is that supply chain linkages intensify contacts between foreign firms and domestic suppliers. When a foreign firm and a local supplier are part of the same production chain they need to interact and coordinate to guarantee a smooth functioning of the chain. This face-to-face communication will facilitate the transfer of non-codified knowledge. ${ }^{1}$ A recent study by Hovhannisyan and Keller (2011) finds that a 10\% increase in business travel from the United States to a country increases patenting in that country by about $0.2 \%$.

Understanding whether supply chains affect knowledge spillovers and quantifying this effect is important. First, international supply chains are increasingly the dominant way of production worldwide. Technological innovation in transportation and communication services have reduced coordination and trade costs, thus making it easier to separate different segments of the production process among different countries. Over time, international supply chains have expanded geographically moving from being simply north-north, to north-south and more recently south-south (WTR, 2014).

Second, the diffusion of knowledge across countries may be a powerful engine of growth and is a crucial factor in explaining global income distribution. Countries have different levels of productivity not only because they differ in terms of their investment in research and development (R\&D), but also because of their differences in the extent to which they benefit from research done abroad. If discoveries made in a foreign country increase $R \& D$ productivity in the home country (knowledge spillovers), domestic firms have a higher incentive to innovate. This will generate higher growth. As shown in Eaton and Kortum (1999), in the steady state all countries grow at the same higher rate than without spillover. But countries that are quicker to adopt innovation generated at home and abroad take the lead. Understanding the determinants of technology diffusion is crucial to identify "who is getting what from whom" (Eaton and Kortum, 1999, p. 538) and develop appropriate policies. If knowledge spreads internationally through supply chains, then adopting policies to attract vertical FDI or establish supplier development programmes may be justifiable.

Third, not all knowledge transfer, including a transfer through supply chains, represents knowledge spillovers in the traditional economic sense. A supplying firm may need to invest into upgrading its production technology to meet the request of its customer. The existence of a demand for a higher quality product provides an incentive for this investment, but this is linked to the supplier's ability to invest in technology upgrading. Spillovers are the part of technology upgrading for which the firm does not pay (or pays a lower cost than the initial cost of the technology). Furthermore, when a firm outsources a specific task, for example sewing a car seat, it may just lend the technology of that particular task. Thus the host country loses the technology when the car manufacture leaves. This

\footnotetext{
${ }^{1}$ The literature on knowledge transfer has explained that while the codified part of innovation (that for example contained in a patent or in a publication) is likely to be available to any scientist, there is a part of knowledge that is tacit and diffuses only via personal contact.
} 
type of technology flows - that Baldwin (2012) describes as "technology lending" rather than technology spillovers - also provides countries with an opportunity for rapid industrial development, but this growth may stop if the offshoring company moves to another country.

This paper tests whether the research activity and ideas generated in a foreign country, that has supply chain linkages with the host country, influence the R\&D productivity of the host country. In order to capture knowledge spillovers, we measure innovation as the number of patent applications. We depart in this way from the existing literature that generally measures knowledge spillovers by total factor productivity. ${ }^{2}$ The advantage of focusing on R\&D productivity rather than TFP is that the latter is directly affected by the use of foreign intermediate inputs in production and by "technology lending" while the former is not. If the home country imports high-tech inputs, domestic TFP may increase because these inputs have higher price-adjusted quality. Yet, the increase in TFP in this case does not reflect the fact that the importing country has acquired the knowledge embodied in these goods. In this way, focusing on spillovers to innovation provides a lower bound estimates of potential benefits from international supply chain participation.

Ours is the first paper that explores the impact of supply chains on knowledge spillovers in a sample of 29 economies covering the three main production networks in the world, namely Factory Asia, North-America and Central-Eastern Europe. ${ }^{3}$ Most of the existing literature on this topic focuses on individual countries or on a subsample of OECD countries. ${ }^{4}$ Furthermore, thanks to a recently built database of international input-output tables, we are able to account for the actual geographical distribution of the imported foreign inputs of all countries. Previous studies instead had to assume the same geographical distribution for intermediates and final goods or assume that countries had the same input-output structure of the US. ${ }^{5}$

An issue often discussed in the literature is that of the identification of $\mathrm{R} \& \mathrm{D}$ spillovers. If, for example, new technology opportunities arise in a certain sector, firms in all countries will invest more in $R \& D$ in that sector and, at the same time, will be more likely to innovate. This effect may erroneously be measured as a spillover. We address this problem in three ways. First, we run a panel regression on the subsample of countries for which we have the time series. We use lagged values of R\&D and control for industry-year specific effects. Second, relying on the assumption that R\&D in large economies at the technology frontier is less likely to depend on opportunities arising in smaller countries, we look at the impact of $\mathrm{R} \& \mathrm{D}$ conducted in five advanced economies on innovation in other countries. Third, we also use an instrumental variable approach, where the instrument for foreign $\mathrm{R} \& \mathrm{D}$ is the interaction between the industry's dependence on external financing and the degree of the foreign country's financial sector development.

Our results support the view that supply chains are a potential channel of international knowledge spillovers. Countries participating in supply chains acquire part of the knowledge of the sending country and increase their domestic R\&D productivity. Most importantly, spillovers are stronger the stronger the supply chain relationship between the technology sender and the user (when a country

\footnotetext{
${ }^{2}$ Using TFP as the dependent variable, the existing literature usually supports the view that supply chains foster knowledge spillovers. Some studies show that the use of foreign intermediates is correlated with industry productivity, mainly within the same industry and for high technology goods (Keller, 2002a; Nishioka and Ripoll, 2012). Other studies show that productivity is correlated with vertical FDI. Several firm-level studies reveal that firms supplying multinationals are not only the most productive to start with, but they also learn from their relationship with the multinationals (Javorcik, 2004; Iacovone et al., 2011; Javorcik and Spatareanu, 2009).

${ }^{3}$ In our sample, Factory Asia is represented by China, Chinese Taipei, Japan and South Korea; Factory NorthAmerica by Canada, Mexico and USA; and Factory Central-Eastern Europe by Austria, Germany, Czech Republic, Hungary, Poland, Romania, Slovak Republic, Slovenia.

${ }^{4}$ For example, Keller and Yeaple (2009) focus on the United States, Goto and Suzuki (1989) on Japan, Javorcik (2004) on Lithuania, Javorcik and Spatareanu (2009) on the Czech Republic; Iacovone et al. (2011) on Mexico. Other studies that explore the role of FDI or imported intermediates on knowledge spillovers include: Keller (1998, 2000, 2002a) and Lichtenberg and Pottelsberghe de la Potterie (2001). They all focus on a subset of OECD countries.

${ }^{5}$ See Keller (2002a) and Nishioka and Ripoll (2012).
} 
offshores the production of certain components to re-import them).

We also show that the traditional finding that knowledge spillovers depend on geographical distance holds. But only to the extent that distance is correlated with the intensity of supply chains. We find that stronger supply chain linkages are associated with less geographically localized knowledge spillovers. On the basis of this result, we argue that the expansion of international supply chains may explain the de-localization of knowledge spillovers. Keller (2002b) estimates that knowledge flows at a distance of $2000 \mathrm{~km}$ between senders and receivers increased from $5 \%$ to $50 \%$ between the periods 1973-83 and 1986-95. It may not be a coincidence that precisely the period between 1985 and 1995 witnessed the fastest growth of supply chains - a period that Baldwin (2012) identifies as the "second unbundling".

The rest of the paper is organized as follows: Section 2 discusses the analytical framework and our empirical strategy. Section 3 describes the data and provides some stylized facts. Section 4 shows our results. Section 5 investigates robustness of the results and Section 6 presents an extension. Section 7 discusses potential endogeneity issues and Section 8 concludes.

\section{The Model}

\subsection{Analytical Framework}

In order to analyze how R\&D activity in one country influences innovative output of other country, we rely on a standard innovation production function. Endogenous growth theory (Romer, 1990; Grossman and Helpman, 1991a,b; Eaton and Kortum, 1999) models innovation as a process that depends not only on private and excludable inputs such as $R \& D$ investment, but also on the public stock of knowledge generated in the past and by the R\&D investment undertaken anywhere around the world. Once an idea is discovered it becomes a public good and, as such, it may inspire and accelerate new inventions. Therefore, private investment that generates new profitable inventions also enhances productivity of $\mathrm{R} \& \mathrm{D}$ investment of other inventors, thus generating a positive externality - knowledge spillovers. Yet, as Eaton and Kortum (1999) stress, the rate at which this public knowledge actually diffuses differs across countries. It is often assumed that although a country can draw upon both domestic and foreign stock of knowledge, the latter is less accessible. Eaton and Kortum (1999) find that research performed abroad is about two thirds as powerful as domestic research.

In its general formulation the stock of knowledge actually available to each country is a function, $f$, of the world knowledge generated by investment in $\mathrm{R} \& \mathrm{D}$ at all time and the country-pair specific diffusion parameter $w$. Therefore, the flow of ideas to country $i$ can be written in a generic form:

$$
\text { New ideas } i t=f\left(R \& D_{j t}, w_{i j}\right) \quad \forall i, j, t
$$

There are several reasons why foreign stock of knowledge may be more difficult to draw upon than the domestic one. As Keller (2004) summarizes in his review of the literature on technology diffusion, even if knowledge is non-rival and codified for public use, some knowledge is only partially codifiable. The non-codified part of knowledge can be nevertheless essential for follow-up innovations. This type of knowledge is often transferred through face-to-face communication and therefore the degree of such interactions between researchers will be a crucial determinant of knowledge spillovers. It is in general assumed that interactions between researchers located in different countries are more difficult, and so is the transmission of non-codified knowledge.

Our hypothesis is that the accessibility of foreign knowledge depends on supply chain linkages between countries. Our argument is that international economic relations that involve a high degree of coordination and cooperation increase the degree of face-to-face communication and therefore facilitate the transfer of non-codified knowledge. International supply chains trade is an indicator of 
such relations. International production sharing involves a high degree of interdependency between producers from different countries. Production of a good in one country depends on a timely delivery of inputs from a factory abroad and these inputs need to be perfectly compatible with the domestic production line. Furthermore, high-skilled personnel often flow within multinational firms across borders to assure technological as well as managerial cohesion across production units in different countries. Therefore, we expect that countries whose production processes are more interdependent interact more, and that this in turn facilitates transfer of knowledge.

\section{$2.2 \quad$ Empirical Model}

Using the number of patents as a proxy for innovation, the equation we estimate is:

$$
\text { Patent }_{i k}=\exp \left(\alpha+\beta \cdot \ln (R \& D)_{i k}+\gamma \cdot \sum_{j \neq i} w_{i j k} \cdot \ln (R \& D)_{j k}+\iota+\kappa\right)+\epsilon_{i k}
$$

where subscript $i$ denotes the home country, $j$ the foreign country and $k$ denotes an industry. ${ }^{6}$ For simplicity of the exposition we denote hereafter the weighted average of foreign R\&D investment $\sum_{j \neq i} w_{i j k} \cdot \ln (R \& D)_{j k}$ as $R \& D$ Pool $_{i k}$.

We estimate equation (2) using country and industry fixed effects $(\iota$ and $\kappa$ ) or adding a set of control variables. Country-specific determinants are the size of home market which influences the profitability of patenting an innovation, the level of economic development, human capital and the institutional environment. Industry-specific factors are for example the differences between the propensities to patent innovation across industries or the differences in the importance of incremental innovation.

Patenting data are non-negative and unbounded from above which suggests using an econometric model where the conditional mean is assumed to be an exponential function of the regressors. Following the literature that estimates patent production functions (see e.g. Cameron and Trivedi 1998) we estimate equation (2) using a negative binomial estimator. ${ }^{7}$

\section{Data}

\subsection{Innovation}

Our measure of innovation is the number of patent applications filed under the Patent Cooperation Treaty (PCT) by inventor's residence. The advantage of using the number of PCT patent applications over applications at a single patent office is threefold. First, single patent offices may be chosen because of stronger trade and FDI linkages. Therefore, for the purpose of our study, using a single patent office may bias our estimation by construction. Second, patents filed through PCT designate automatically all PCT member states and thus can be viewed as "worldwide" applications. ${ }^{8}$ The PCT procedure has been used increasingly by all member states and since the early 2000s most countries are well represented (OECD, 2009). Third, the costs of PCT applications tend to be higher than the costs of filing domestically. Hence, PCT applications guarantee a minimum level of value for the patent. Counting patent applications by inventor's residence indicates the inventiveness of the local laboratories and labour force of a given country. Finally, to capture the closest date in the patenting process to the actual invention, we use the number of patent applications measured by priority date.

\footnotetext{
${ }^{6}$ We focus our analysis on intra-industry knowledge spillovers. Empirical literature finds in general inter-industry spillovers to be low and insignificant compared to intra-industry spillovers (Nishioka and Ripoll, 2012). In addition, the high level of aggregation (ISIC 2 and higher) of our analysis makes it likely that all spillovers are intra-industry.

${ }^{7}$ Note that our patenting data are fractional counts - if a patent has $\mathrm{N}$ inventors from different countries, each country is attributed $1 / \mathrm{N}$ patents - and therefore Patents is not a count variable. Nevertheless it is well established that a quasi-maximum-likelihood estimator (QMLE) approach does not require the dependent variable to be discrete.

${ }^{8}$ Before 2004 applicants had to select which markets they wanted to target and therefore the statistics include applications that designated the European Patent Office.
} 
Data on patent applications come from the OECD Patent Statistics. Using the new concordance tables developed by Lybbert and Zolas (2012), we convert patent data classified by patent technology into ISIC rev.3 industry classification.

\section{$3.2 \quad$ R\&D Pool}

In order to test whether knowledge flows through supply chains, we assume that the weights in the formula for $R \& D$ Pool $_{i k}$ in equation (2) are based on supply chain linkages $(S L)$ between a foreign knowledge source country and a home country. Then we test whether the $R \& D P o o l_{i k}$ is a significant determinant of the productivity of domestic R\&D in equation (2).

We construct four measures of international supply chain linkages. The first measure represents supply chains trade in the broadest sense. It is the value of imported intermediate inputs from industry $k$ in country $j$ to industry $k$ in country $i$. Using the terminology of Baldwin and Lopez-Gonzalez (2013), we denote this measure imports to produce (I2P). A narrower definition of supply chains trade is the value of imported intermediates that is processed for exports (I2E), i.e. the value of imported intermediate inputs that industry $k$ in country $i$ imports from industry $k$ in country $j$ and that is used for exports from industry $k$ in country $i$. Our third measure restricts the definition of international supply chains even more and considers only the value of imported intermediate inputs that are re-exported back to country $j$ - imports of intermediates to re-export (I2RE). Finally, our fourth measure of international supply chain linkages only accounts for the value of imported intermediate inputs that are re-exported as inputs - imports of intermediates to re-export for further processing (I2REP). The first two measures capture a one-way flow from country $j$ to country $i$, while the other two measures capture reciprocal relationships where goods cross the same boundary at least twice first as an input, then embodied in exported goods.

Using the international input-output tables available from the World Input-Output Database $(\mathrm{WIOD})^{9}$, we calculate these four measures as:

$$
\begin{aligned}
& \mathrm{I} 2 \mathrm{P}=\text { Intermediates }_{j i k}{ }^{10} \\
& \mathrm{I} 2 \mathrm{E}=\text { Intermediates }_{j i k} / \text { Output }_{i k} \cdot \text { Exports }_{i k} \\
& \mathrm{I} 2 \mathrm{RE}=\text { Intermediates }_{j i k} / \text { Output }_{i k} \cdot \text { Exports }_{i j k} \\
& \mathrm{I} 2 \mathrm{REP}=\text { Intermediates }_{j i k} / \text { Output }_{i k} \cdot \text { Intermediates }_{i j k} .
\end{aligned}
$$

To simplify the interpretation of the coefficients for the variable $R \& D P$ ool in our regressions, we construct the SL weights by taking the logarithm and then standardizing each of the measures above (I2P, I2E, I2RE and I2REP) by its maximum. Therefore, our weights range from 0 to 1 and the coefficient for $R \& D P o o l_{i k}$ represents the elasticity of innovation with respect to $R \& D$ when the intensity of supply chain linkages is at its highest. ${ }^{11}$

To test the robustness of our results, we also calculate a distance-weighted foreign R\&D Pool. Following the existing literature ${ }^{12}$, we calculate this alternative pool as:

$$
R \& D P o o l \_D_{i k}=\sum_{j \neq i}\left[\ln (R \& D)_{j k} \cdot \exp (-D)_{i j}\right],
$$

where $D_{i j}$ is the distance between largest cities in thousands kilometers. Data for distance are from CEPII.

\footnotetext{
${ }^{9}$ http://www.wiod.org/database/index.htm

${ }^{10}$ The subscript $j i k$ denotes the country of origin, the country of destination and industry respectively so that for instance Intermediates $_{j i k}$ are imports of intermediates from country $j$ to country $i$ within industry $k$.

${ }^{11}$ To be precise, our SL weight is defined as $\ln \left(1+S L_{i j k}\right) / \max \left\{\ln \left(1+S L_{i j k}\right)\right\}$, where SL $=\{\mathrm{I} 2 \mathrm{P}, \mathrm{I} 2 \mathrm{E}, \mathrm{I} 2 \mathrm{RE}, \mathrm{I} 2 \mathrm{REP}\}$. The standardization does not influence our results.

${ }^{12}$ See Keller (2004) and Bottazzi and Peri (2003).
} 
We run our analysis for eight manufacturing industry groups. This is the most disaggregated level of analysis we can perform given the available data. Data on business R\&D expenditures come from the OECD Research and Development Statistics and are downloaded at the two-digit ISIC Rev.3 level. Our sample covers thirteen two-digit industries which account for more than $90 \%$ of business R\&D spending in manufacturing ${ }^{13}$. However, to construct the production networks weights, we use the world input-output tables from the World Input-Output Database (WIOD) where manufacturing industries are aggregated into eight groups, and hence we use these industry groups throughout our analysis. $^{14}$

\subsection{Other variables - country characteristics}

Our preferred specification of the empirical model is one with country and sector fixed effects. However, as a robustness, to test that our model provides the expected signs for the variables that are usually used in the literature on innovation, we also run regressions using a set of control variables for country characteristics.

Our control variables include: GDP, GDP per capita, a measure of patent protection and research capital. We expect that, since returns to innovation increase with the size of the home market, ceteris paribus, propensity to patent will be higher in countries with bigger markets. We, therefore, include the $\log$ of real GDP $(\ln (G D P))$ as a control. In addition, the propensity to patent an innovation is also likely to depend on the level of development of the country, its institutions and the extent of patent protection in the country. Therefore, we also include the log of real GDP per capita $(\ln (G D P$ per capita $))$ and the log of Index of Patent Protection $(\ln ($ Patent protection $))$ among the controls in our empirical model. Finally, we include the number of researchers in the R\&D sector per capita $(\ln ($ Researchers $))$. This is to control for the possibility that the productivity of business $\mathrm{R} \& \mathrm{D}$ is affected by the degree to which business research can draw upon an extensive knowledge base, including primary research conducted at universities or other sectors.

GDP per capita and population are taken from PENN World Tables. Data for Patent Protection Index are obtained from Park (2008). ${ }^{15}$ As a measure of human capital we use the number of researchers in the R\&D sector per capita which comes from WIPO.

\subsection{Sample size and long run averages}

Our analysis is run over a cross section of long-run averages over the period $2000-2008^{16}$ for 29 countries and 8 sectors. This is the largest possible sample for which data for our variables are available, and presents the advantage that it covers a sufficiently recent time period allowing us to capture the latest structural changes that took place in the world with the emergence of new global players such as China.

We use long-run averages rather than time series in our benchmark specification for several rea-

\footnotetext{
${ }^{13}$ OECD average in 2008.

${ }^{14}$ The industry groups are: Manufacture of coke, refined petroleum products and nuclear fuel (23), Manufacture of chemicals and chemical products (24), Manufacture of rubber and plastics products (25), Manufacture of other nonmetallic mineral products (26), Manufacture of basic metals and of fabricated metal products, except machinery and equipment (27 to 28), Manufacture of machinery and equipment n.e.c. (29), Manufacture of office, accounting and computing machinery, of electrical machinery and apparatus n.e.c., of radio, television and communication equipment and apparatus and of medical, precision and optical instruments, watches and clocks (30 to 33), Manufacture of motor vehicles, trailers and semi-trailers and of other transport equipment (34 to 35).

${ }^{15}$ The index is the unweighted sum of five separate scores for coverage (inventions that are patentable); membership in international treaties; duration of protection; enforcement mechanisms; and restrictions. It indicates the strength of protection in the country.

${ }^{16}$ The Patent Protection Index is available only for the years 2000 and 2005, so the average is taken over these two years.
} 
sons. First, we know from the literature ${ }^{17}$ that the number of patents and the amount of resources spent in R\&D are more likely to be correlated in the long-run than in the short-run. This is because it may take several years before R\&D expenditure generates an innovation. Second, long-run averages help to address the issue of the variability in a patent's value from one year to another. Nevertheless, we run panel regressions as a robustness.

\subsection{Summary statistics and preliminary analysis}

Table 1 reports the share of each sector in the total $R \& D$ expenditures and patent applications in the sample. The category Manufacture of machinery, ITC equipment and medical, precision and optical instruments, watches and clocks (ISIC 30 to 33) accounts for the largest share of R\&D expenditures as well as the largest share of patent applications. Manufacture of transport equipment (ISIC 34 to 35) and Manufacture of chemicals (ISIC 24) also account for a large share of R\&D expenditures.

Table 1: Summary of main variables by industry

\begin{tabular}{llll}
\hline Industry & $\begin{array}{l}\text { R\&D expenditures } \\
\text { \% of total }\end{array}$ & $\begin{array}{l}\text { Patent applications } \\
\text { \% of total }\end{array}$ & $\begin{array}{l}\text { R\&D pool } \\
\text { Share of own R\&D }\end{array}$ \\
\hline ISIC 23 & 0.92 & 10.61 & 0.13 \\
ISIC 24 & 21.33 & 25.12 & 1.65 \\
ISIC 25 & 2.11 & 2.66 & 0.25 \\
ISIC 26 & 1.14 & 4.31 & 0.11 \\
ISIC 27 to 28 & 4.09 & 6.77 & 1.94 \\
ISIC 29 & 8.82 & 12.31 & 0.69 \\
ISIC 30 to 33 & 38.32 & 32.70 & 2.08 \\
ISIC 34 to 35 & 23.26 & 5.53 & 1.92 \\
\hline
\end{tabular}

Notes: ISIC code 23 indicates Manufacture of coke, refined petroleum products and nuclear fuel, 24 Manufacture of chemicals and chemical products, 25 Manufacture of rubber and plastics products, 26 Manufacture of other non-metallic mineral products, 27 to 28 Manufacture of basic metals and of fabricated metal products, except machinery and equipment, 29 Manufacture of machinery and equipment n.e.c., 30 to 33 Manufacture of office, accounting and computing machinery, of electrical machinery and apparatus n.e.c., of radio, television and communication equipment and apparatus and of medical, precision and optical instruments, watches and clocks, 34 to 35 Manufacture of motor vehicles, trailers and semi-trailers and of other transport equipment.

Table 2 reports the share of each country in total $R \& D$ expenditures and patent applications in the sample. The distribution of R\&D expenditures is very concentrated. USA, Japan and Germany account for $67 \%$ of total R\&D expenditures in our sample, and, together with China, France, Korea and the United Kingdom, they add up to almost $90 \%$. Patent applications are similarly concentrated in those countries. The last column shows the relative importance of the foreign R\&D pool to home $R \& D$ spending. The foreign $R \& D$ pool matters relatively more in countries that are highly integrated in international supply chains, both in large rich countries such as Germany, France or Belgium and in smaller or poorer economies such as Czech Republic, Chinese Taipei or China.

${ }^{17}$ Griliches (1990, p.1673-1674) and Bottazzi and Peri (2003). 
Table 2: Summary of main variables by country

\begin{tabular}{|c|c|c|c|}
\hline Country & $\begin{array}{l}\text { R\&D expenditures } \\
\% \text { of total }\end{array}$ & $\begin{array}{l}\text { Patent applications } \\
\% \text { of total }\end{array}$ & $\begin{array}{l}\text { R\&D pool } \\
\text { Share of own } R \& D\end{array}$ \\
\hline Australia & 0.53 & 1.24 & 0.38 \\
\hline Austria & 0.77 & 0.93 & 1.17 \\
\hline Belgium & 0.73 & 1.00 & 1.80 \\
\hline Canada & 1.59 & 2.01 & 1.21 \\
\hline China & 7.66 & 2.28 & 1.44 \\
\hline Chinese Taipei & 2.04 & 0.13 & 1.38 \\
\hline Czech Republic & 0.28 & 0.12 & 1.36 \\
\hline Estonia & 0.01 & 0.02 & 0.15 \\
\hline Finland & 0.18 & 1.02 & 1.00 \\
\hline France & 5.04 & 5.05 & 1.74 \\
\hline Germany & 10.16 & 14.53 & 2.80 \\
\hline Greece & 0.05 & 0.07 & 0.16 \\
\hline Hungary & 0.13 & 0.16 & 1.23 \\
\hline Ireland & 0.18 & 0.33 & 0.97 \\
\hline Italy & 1.58 & 2.16 & 1.32 \\
\hline Japan & 20.22 & 19.88 & 1.00 \\
\hline Korea & 4.80 & 3.46 & 1.19 \\
\hline Mexico & 0.26 & 0.14 & 0.95 \\
\hline Netherlands & 1.00 & 3.48 & 1.59 \\
\hline Poland & 0.14 & 0.10 & 1.10 \\
\hline Portugal & 0.07 & 0.06 & 1.00 \\
\hline Romania & 0.06 & 0.03 & 0.53 \\
\hline Russian Federation & 0.69 & 0.58 & 0.28 \\
\hline Slovak Republic & 0.03 & 0.03 & 1.19 \\
\hline Slovenia & 0.09 & 0.09 & 0.57 \\
\hline Spain & 0.97 & 0.88 & 1.20 \\
\hline Turkey & 0.26 & 0.19 & 0.59 \\
\hline UK & 4.01 & 4.68 & 1.60 \\
\hline USA & 36.5 & 35.34 & 1.42 \\
\hline
\end{tabular}

A simple descriptive analysis of the correlation between the number of patents and the pool of foreign $R \& D$ shows interesting results. Our data show that there is a positive correlation between our supply chains-weighted R\&D pool and innovation. This positive correlation also holds for other subsamples, for example, that of EU countries (right panel of Figure 1). ${ }^{18}$ Interestingly, when we run the correlation for the distance-weighted $\mathrm{R} \& \mathrm{D}$ pool, we only observe a positive correlation for the subsample of countries and not for the full sample.

\section{Results}

Table 3 shows our estimates of knowledge spillovers for the four measures of supply chain linkages we use in our analysis. Our results support the evidence that knowledge spillovers within supply chains do occur. In particular, the magnitude of knowledge spillovers appears to decrease with the broadness of the measure of supply chains we use as weight in the R\&D pool (columns (1) to (4)). A narrower definition of supply chains is more likely to capture a close relationship between the consumer and the supplier of the intermediate input. The argument is the following. When an intermediate input is specifically designed to match the needs of a single final good producer (as it is likely to be the case if a component is imported from and re-exported to the same country), the final good producer

\footnotetext{
${ }^{18}$ Countries that were EU members throughout the sample period are Austria, Belgium, Finland, France, Germany, Greece, Ireland, Italy, the Netherlands, Portugal, Spain and the United Kingdom.
} 

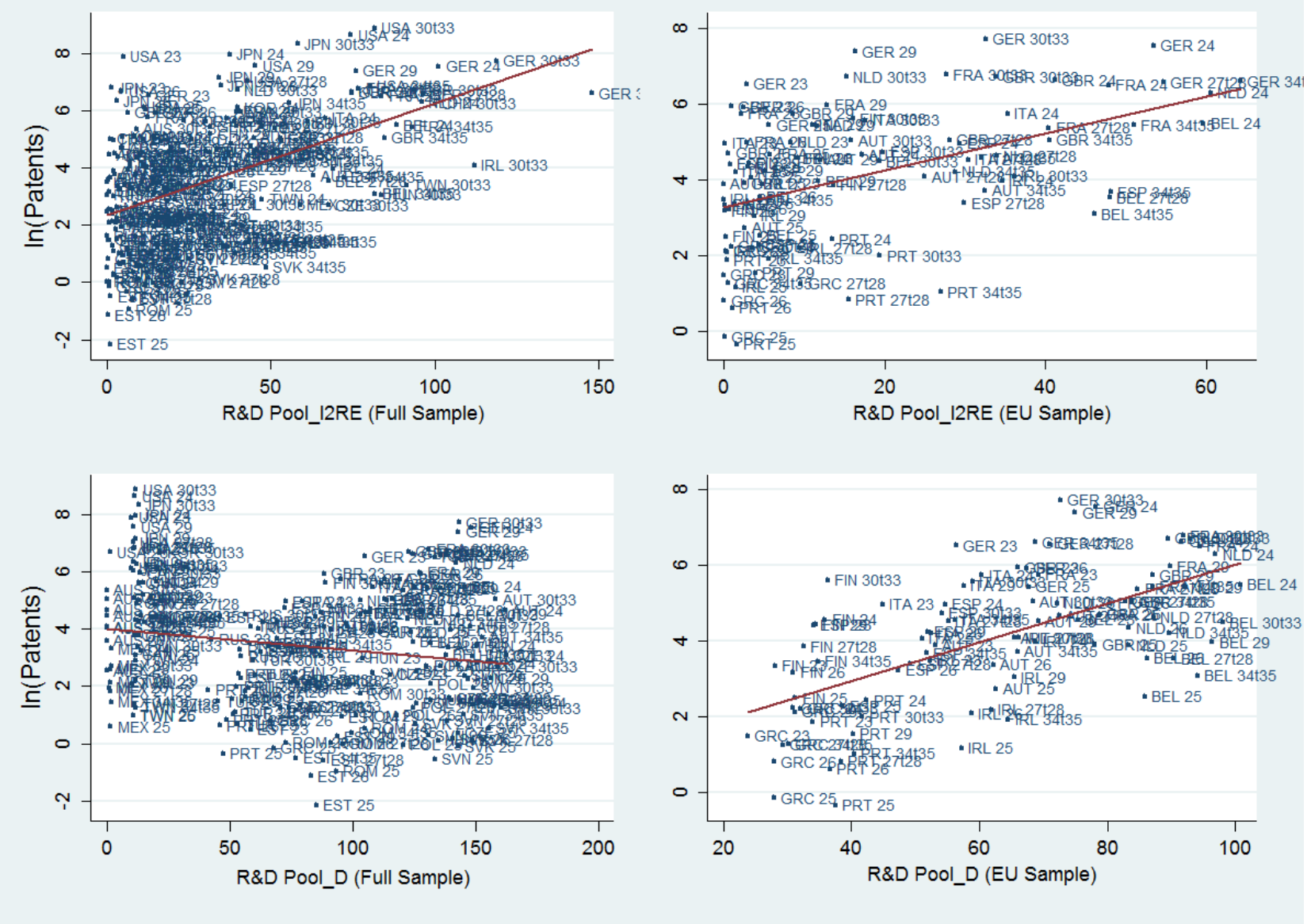

Figure 1: Number of patents (in log) and the R\&D Pool

may "hold-up" the supplier. ${ }^{19}$ One way to reduce the risk of the hold-up problem is for the final good producer to reduce the cost of investment required for the customization of the input to its own need and monitor production. This includes providing the technology required for the customization (which will reduce the cost of investment) and increasing face-to-face interaction to ensure the adequate investment in technology learning by the local supplier. ${ }^{20}$ Both options imply larger knowledge spillovers.

We find robust evidence that knowledge spillovers are positive and significant only for the two most restrictive definitions of supply chains - that is, for the case in which firms in country $i$ import a component from country $j$, process it and re-export the processed good back to country $j$ (columns $(3),(4),(7)$ and (8)). In the country fixed effects specification, the foreign R\&D pools weighted by imported intermediates used for total exports (I2E) and by imports of intermediate goods (I2P) - that is including inputs processed for domestic sales - have no statistically significant effects (columns (5) and (6)). This suggests that only linkages that involve inputs crossing the same border back and forth are important channels for knowledge spillovers.

Using the results in column (5), the elasticity of home patenting with respect to foreign $\mathrm{R} \& \mathrm{D}$ is $0.0042 \%$ for observations with the most intensive production links, such as the United States and Canada in Transport equipment, the United States and Mexico in Transport equipment and Electrical machinery, or China and Chinese Taipei in Electrical machinery. That is to say that, if the United States doubles its R\&D in transport equipment, the number of innovations in the sector in Canada

\footnotetext{
${ }^{19}$ This is because after the investment, the good has little market value outside the contractual relationship. Therefore, the input supplier has little bargaining power and the producer of the final good can breach the contract. Anticipating this possibility, the input supplier will under-invest, and thus outsourcing would be inefficient.

${ }^{20}$ Tirole (1998).
} 
Table 3: Knowledge spillovers through supply chains
(1)
$(2)$
(3)
(4)
(5)
(6)
(7)
$(8)$

Dependent: Patents

\begin{tabular}{|c|c|c|c|c|c|c|c|c|}
\hline R\&D Pool_I2P & $\begin{array}{l}0.0030^{*} \\
(0.0017)\end{array}$ & & & & $\begin{array}{l}0.0007 \\
(0.0010)\end{array}$ & & & \\
\hline R\&D Pool_I2E & & $\begin{array}{l}0.0028^{* *} \\
(0.0013)\end{array}$ & & & & $\begin{array}{l}0.0007 \\
(0.0009)\end{array}$ & & \\
\hline R\&D Pool_I2RE & & & $\begin{array}{l}0.0071^{* * *} \\
(0.0024)\end{array}$ & & & & $\begin{array}{l}0.0029^{*} \\
(0.0017)\end{array}$ & \\
\hline R\&D Pool_I2REP & & & & $\begin{array}{l}0.0087^{* * *} \\
(0.0025)\end{array}$ & & & & $\begin{array}{l}0.0042^{* *} \\
(0.0018)\end{array}$ \\
\hline $\ln (\mathrm{R} \& \mathrm{D})$ & $\begin{array}{l}0.259 * * * \\
(0.0755)\end{array}$ & $\begin{array}{l}0.253^{* * *} \\
(0.0758)\end{array}$ & $\begin{array}{l}0.246^{* * *} \\
(0.0728)\end{array}$ & $\begin{array}{l}0.252^{* * *} \\
(0.0708)\end{array}$ & $\begin{array}{l}0.141^{* *} \\
(0.0551)\end{array}$ & $\begin{array}{l}0.139^{* *} \\
(0.0561)\end{array}$ & $\begin{array}{l}0.132^{* *} \\
(0.0546)\end{array}$ & $\begin{array}{l}0.129^{* *} \\
(0.0524)\end{array}$ \\
\hline $\ln (\mathrm{GDP})$ & $\begin{array}{l}0.696^{* * *} \\
(0.118)\end{array}$ & $\begin{array}{l}0.738^{* * *} \\
(0.116)\end{array}$ & $\begin{array}{l}0.735^{* * *} \\
(0.113)\end{array}$ & $\begin{array}{l}0.729^{* * *} \\
(0.113)\end{array}$ & & & & \\
\hline $\ln ($ GDP per capita $)$ & $\begin{array}{l}0.523^{*} \\
(0.276)\end{array}$ & $\begin{array}{l}0.491^{*} \\
(0.275)\end{array}$ & $\begin{array}{l}0.469^{*} \\
(0.280)\end{array}$ & $\begin{array}{l}0.486^{*} \\
(0.281)\end{array}$ & & & & \\
\hline $\ln$ (Researchers) & $\begin{array}{l}0.588^{* * *} \\
(0.109)\end{array}$ & $\begin{array}{l}0.606^{* * *} \\
(0.112)\end{array}$ & $\begin{array}{l}0.609^{* * *} \\
(0.112)\end{array}$ & $\begin{array}{l}0.595^{* * *} \\
(0.107)\end{array}$ & & & & \\
\hline $\ln ($ Patent protection $)$ & $\begin{array}{l}3.558^{* * *} \\
(1.231)\end{array}$ & $\begin{array}{l}3.422^{* * *} \\
(1.234)\end{array}$ & $\begin{array}{l}3.451^{* * *} \\
(1.227)\end{array}$ & $\begin{array}{l}3.572^{\text {*** }} \\
(1.197)\end{array}$ & & & & \\
\hline Industry dummies (8) & yes & yes & yes & yes & yes & yes & yes & yes \\
\hline Country dummies (29) & no & no & no & no & yes & yes & yes & yes \\
\hline Observations & 201 & 201 & 201 & 201 & 225 & 225 & 225 & 225 \\
\hline
\end{tabular}

Country-clustered standard errors in parentheses

$* * * \mathrm{p}<0.01, * * \mathrm{p}<0.05, * \mathrm{p}<0.1$

increases by $0.4 \%$. The elasticity declines rapidly with weaker supply chains links. It is $0.03 \%$ for the observations at the 90 th percentile of the I2REP distribution and only $0.003 \%$ for the observations at the 75 th percentile.

\section{Robustness}

\subsection{Distance-weighted R\&D pool}

One established finding of the empirical literature is that knowledge spillovers are not global but local. In other words, global knowledge is not a public good from which anyone can source, rather the extent to which a country benefits, in terms of productivity growth, from the knowledge created abroad falls with its distance from the knowledge originating country. Keller (2002b), estimates that, at a distance of 162 kilometers between the sender and the receiver, $50 \%$ of foreign knowledge gets to the receiver, while at 2,000 kilometers only $5 \%$ of knowledge is absorbed. Using the number of patents as measure of innovation, Bottazzi and Peri (2003) find that spillovers are localized and exist only within a distance of $300 \mathrm{~km} .{ }^{21}$ In their non-parametric estimates, they find that doubling R\&D spending in a region would increase the output of new ideas in other regions within $300 \mathrm{~km}$ by $2-3 \%$.

In Table 4 we test the robustness of our results to the inclusion of the distance-weighted R\&D pool. Column (1) reports again the result for R\&DPool_I2REP for comparison with columns (2)

\footnotetext{
${ }^{21}$ An earlier study by Jaffe et al. (1993) that uses patent citation as a measure of technological spillovers also emphasize that knowledge spillovers are local. They find that US patents are more often cited in other US patents than in patents of other countries.
} 
Table 4: Distance decay of knowledge spillovers

\begin{tabular}{|c|c|c|c|c|c|c|}
\hline \multirow[b]{2}{*}{ Dependent: Patents } & \multicolumn{3}{|c|}{ Full Sample } & \multicolumn{3}{|c|}{ EU Sample } \\
\hline & (1) & $(2)$ & $(3)$ & $(4)$ & $(5)$ & $(6)$ \\
\hline R\&D Pool_I2REP & $\begin{array}{c}0.0042^{* *} \\
(0.0018)\end{array}$ & & $\begin{array}{c}0.0044^{* *} \\
(0.0018)\end{array}$ & $\begin{array}{l}0.0084^{*} \\
(0.0045)\end{array}$ & & $\begin{array}{l}0.0078 \\
(0.0053\end{array}$ \\
\hline R\&D Pool_D & & $\begin{array}{l}-0.0056 \\
(0.0035)\end{array}$ & $\begin{array}{c}-0.0061^{*} \\
(0.0036)\end{array}$ & & $\begin{array}{l}0.0200^{*} \\
(0.0110)\end{array}$ & $\begin{array}{l}0.0081 \\
(0.0152)\end{array}$ \\
\hline $\ln (\mathrm{R} \& \mathrm{D})$ & $\begin{array}{l}0.124^{* *} \\
(0.055)\end{array}$ & $\begin{array}{l}0.154^{* * *} \\
(0.055)\end{array}$ & $\begin{array}{l}0.133^{* *} \\
(0.057)\end{array}$ & $\begin{array}{l}0.125 \\
(0.098)\end{array}$ & $\begin{array}{l}0.165^{*} \\
(0.089)\end{array}$ & $\begin{array}{l}0.132 \\
(0.099)\end{array}$ \\
\hline Industry dummies (8) & yes & yes & yes & yes & yes & yes \\
\hline Country dummies $(29 / 12)$ & yes & yes & yes & yes & yes & yes \\
\hline Observations & 225 & 225 & 225 & 91 & 91 & 91 \\
\hline
\end{tabular}

Country-clustered standard errors in parentheses

*** $\mathrm{p}<0.01,{ }^{* *} \mathrm{p}<0.05,{ }^{*} \mathrm{p}<0.1$

Notes: EU Sample includes Austria, Belgium, Finland, France, Germany, Greece, Ireland, Italy,

The Netherlands, Portugal, Spain and the United Kingdom.

and (3) which show that distance is not a good proxy for spillover channels and that the coefficient on the R\&DPool_I2REP retains the same magnitude and statistical significance when both R\&D pool measures are included in a regression. We also test the robustness of this result to the sample size. In column (4) we show that our finding that supply chains matter for knowledge spillovers also holds for a subsample of EU economies. For this subsample we also estimate a positive and significant coefficient for the distance-weighted pool of foreign $\mathrm{R} \& \mathrm{D}$, which is in line with previous literature that finds a positive and significant coefficient for the distance-weighted pool within the EU. Both pools turn statistically insignificant when we include them together in one regression (column (6)). Yet, the I2REP pool retains a similar coefficient as in column (4). The imprecision might be driven by multicollinearity because the two pools are highly correlated within the EU sample.

\subsection{Knowledge spillovers through imports}

Empirical literature on international R\&D spillovers has often discussed the role of trade as a channel of knowledge spillovers. ${ }^{22}$ As pointed out in Pisano and Shih (2012), a new design can only be properly manufactured if the designer and the manufacturer interact. Furthermore, new ideas for innovative design can only be generated if the designer understands the manufacturing process. This two-way interaction is strongest in international production networks. It follows that knowledge spillovers conducive to innovation should be stronger within production networks than simply via trade.

In Table 5 we test the robustness of our results when we allow for total trade to work as a channel for technology transfer. To this purpose, we construct a trade-weighted measure of foreign R\&D pool, where the R\&D expenditure in country-industry $j k$ is weighted by its imports to country $i\left(\right.$ Trade $\left._{i j k}\right)$.

We allow for two specifications of the weights. One specification functionally corresponds to our supply chains weights:

$$
R \& D P o o l \_T r a d e(\text { value })_{i k}=\sum_{j \neq i} \ln (R \& D)_{j k} \cdot \ln \left(1+\text { Trade }_{i j k}\right) .
$$

\footnotetext{
${ }^{22}$ For a review see Keller (2010).
} 
The other specification follows previous literature ${ }^{23}$ and uses the share of bilateral imports in the output of country-industry $j k$ :

$$
R \& D \text { Pool_Trade }(\text { share })_{i k}=\sum_{j \neq i} \ln (R \& D)_{j k} \cdot \frac{\text { Trade }_{i j k}}{\text { Output }_{j k}} .
$$

The results in Table 5 suggest that it is the international supply chains and not merely trade between two countries that drive knowledge spillovers. While the coefficient for the supply chain-weighted R\&D pool is positive and significant, none of the two trade-weighted pools of foreign $R \& D$ appears with a statistically significant coefficient.

Coe and Helpman (1995) use an imports-weighted stock of R\&D to examine international knowledge spillovers. Their study is re-examined in Keller (1998) who uses the same data but generates random weights for the stock of foreign R\&D. Keller shows that using the random weights, the estimated knowledge spillovers are often larger than if the actual import patterns are used. Following Keller's approach, we also test the robustness of our results to the use of random weights. We generate a sample of 1000 random numbers drawn from a uniform distribution $[0,100]$, and apply the same transformation as to our supply chains measures to generate random sets of weights. ${ }^{24}$ We find no evidence of international knowledge spillovers when the random-weighted R\&D pool is employed (column (5)).

Table 5: Knowledge spillovers, imports and random weights

\begin{tabular}{|c|c|c|c|c|c|}
\hline Dependent: Patents & (1) & $(2)$ & (3) & $(4)$ & $(5)$ \\
\hline R\&D Pool_I2REP & & $\begin{array}{l}0.0054^{* * *} \\
(0.0020)\end{array}$ & & $\begin{array}{l}0.0041^{* *} \\
(0.0020)\end{array}$ & \\
\hline R\&D Pool_Trade (value) & $\begin{array}{c}6.35 \mathrm{e}-05 \\
(0.0002)\end{array}$ & $\begin{array}{l}-0.0002 \\
(0.0002)\end{array}$ & & & \\
\hline R\&D Pool_Trade (share) & & & $\begin{array}{l}0.0073^{*} \\
(0.0043)\end{array}$ & $\begin{array}{l}0.0007 \\
(0.0039)\end{array}$ & \\
\hline R\&D Pool_Random & & & & & $\begin{array}{l}-0.0008 \\
(0.00086)\end{array}$ \\
\hline $\ln (\mathrm{R} \& \mathrm{D})$ & $\begin{array}{l}0.145^{* * *} \\
(0.0533)\end{array}$ & $\begin{array}{l}0.126^{* *} \\
(0.0507)\end{array}$ & $\begin{array}{l}0.138^{* * *} \\
(0.0515)\end{array}$ & $\begin{array}{l}0.129^{* *} \\
(0.0526)\end{array}$ & $\begin{array}{l}0.145^{* * *} \\
(0.0023)\end{array}$ \\
\hline Industry dummies (8) & yes & yes & yes & yes & yes \\
\hline Country dummies (29) & yes & yes & yes & yes & yes \\
\hline Observations & 225 & 225 & 225 & 225 & 225 \\
\hline
\end{tabular}

Country-clustered standard errors in parentheses

$* * * \mathrm{p}<0.01, * * \mathrm{p}<0.05, * \mathrm{p}<0.1$

\subsection{Knowledge spillovers from rich economies}

There are several studies that test spillovers from rich developed economies to the rest of the world. Keller (2002b), for example, studies spillovers from G5 economies (France, Germany, Japan, the United Kingdom and the United States) to other nine less rich OECD eonomies. Comin et al. (2013) study how an existing technology diffuses depending on the geographical distance between economies that have already adopted the technology and adopters-to-be. They show that interaction with rich

\footnotetext{
${ }^{23}$ See for example Lichtenberg and Pottelsberghe de la Potterie (1998) for discussion of trade weights

${ }^{24}$ The random weight is generated as $\ln \left(1+R A N D O M_{i j k}\right) / \max \left\{\ln \left(1+R A N D O M_{i j k}\right)\right\}$.
} 
economies affects technology adoption significantly more than interactions with poor economies.

If the knowledge pool from rich economies diffuses more easily (because, for example, more resources are spent by the knowledge receiving economies to absorb the knowledge embodied in these new ideas) and if, at the same time, rich economies tend to develop strong production networks, we would have an identification problem. To address these concerns, we run a set of regressions where we split the production-weighted pool of R\&D into one originating from G5 economies (R\&D Pool_I2REP from G5) and another generated by the rest of the economies (R\&D Pool_I2REP from non G5). In addition, we look at the impact of these two pools on innovation of G5 and other economies, respectively.

Table 6: Spillovers from G5 and non-G5 economies

\begin{tabular}{lll}
\hline & \multicolumn{2}{c}{ Sample } \\
& G5 & non-G5 \\
\hline R\&D Pool_I2REP from G5 & 0.0010 & $0.0073^{*}$ \\
& $(0.0035)$ & $(0.0041)$ \\
R\&D Pool_I2REP from non-G5 & $0.0029^{* *}$ & $0.0115^{* *}$ \\
& $(0.0013)$ & $(0.0052)$ \\
\hline
\end{tabular}

Notes: The coefficient estimates are from regressions with the same specification as in Table 3, column (5).

Table 6 shows the results. For the sample of non-G5 economies, we estimate a positive and significant coefficient for both the R\&D pool from G5 economies and the R\&D pool from all other economies. For the sample of G5 economies, we estimate a positive and significant effect for the R\&D pool of non-G5 economies. These results appear to suggest that knowledge spillovers are not just one way (from north to south, from developed to developing economies). We find evidence of significant knowledge spillovers among developing economies when they belong to the same supply chain.

\section{Extension}

We also test our claim that production networks drive knowledge spillovers following an alternative approach. In line with the traditional literature, we assume that spillovers decay with distance. However, for each country, we assume that the knowledge sourcing countries constituting the R\&D pool are only those that are linked to the knowledge receiving country by strong supply chains.

We create an indicator function which takes a value of one for observations with the SL weight above a certain threshold (we define this threshold alternatively as the median, the 75th and the 90th percentiles of the sample distribution). That is, the pool of foreign knowledge that country $i$ has available is assumed to be:

$$
\begin{aligned}
R \& D P o o l \_D \_S L_{i k}=\sum_{j \neq i}\left[\ln (R \& D)_{j k} \cdot \exp (-D)_{i j} \cdot I_{i j k}\right] & \\
\text { where } I_{i j k} & =1 \text { if } S L_{i j k} \geq \text { cutoff } \\
& =0 \text { otherwise }
\end{aligned}
$$

In particular, when the cut-off value is the median of the I2REP weight, we include in our regression the total distance-weighted pool $\left(R \& D P o o l \_D\right)$ and the pool coming only from the above-median linked countries $\left(R \& D P o o l \_D \_I 2 R E P\right)$. The coefficient on the latter then indicates whether and how much the spillovers depend on production linkages for a given distance.

Equipped with this new variable, we re-estimate the model for the full sample. Table 7 reports results of these estimations. While we did not find any distance-related spillovers for the full sample, 
the results in Table 7 do show positive and significant spillovers among countries linked by strong supply chains (columns (2), (3), (5) and (6)). However, when we use country fixed effects, the coefficients for knowledge spillovers turn statistically insignificant.

Table 7: Distance decay of knowledge spillovers from supply chains

\begin{tabular}{|c|c|c|c|c|c|c|}
\hline Dependent: Patents & $\begin{array}{l}(1) \\
50 \text { th }\end{array}$ & $\begin{array}{l}(2) \\
75 \text { th }\end{array}$ & $\begin{array}{l}(3) \\
90 t h\end{array}$ & $\begin{array}{l}(4) \\
50 \text { th }\end{array}$ & $\begin{array}{l}(5) \\
75 \text { th }\end{array}$ & $\begin{array}{l}(6) \\
90 \text { th }\end{array}$ \\
\hline Spillovers from supply chains & $\begin{array}{l}0.003 \\
(0.002)\end{array}$ & $\begin{array}{l}0.001^{* *} \\
(0.002)\end{array}$ & $\begin{array}{l}0.006^{* *} \\
(0.002)\end{array}$ & $\begin{array}{l}0.003 \\
(0.002)\end{array}$ & $\begin{array}{l}0.005^{* *} \\
(0.002)\end{array}$ & $\begin{array}{l}0.006^{* *} \\
(0.003)\end{array}$ \\
\hline R\&D Pool_D & $\begin{array}{l}0.004 \\
(0.004)\end{array}$ & $\begin{array}{l}0.0003 \\
(0.0021)\end{array}$ & $\begin{array}{l}0.001 \\
(0.002)\end{array}$ & $\begin{array}{l}0.003 \\
(0.003)\end{array}$ & $\begin{array}{l}0.0007 \\
(0.002)\end{array}$ & $\begin{array}{l}0.002 \\
(0.002)\end{array}$ \\
\hline R\&D Pool_D_I2REP & $\begin{array}{l}-0.001 \\
(0.004)\end{array}$ & $\begin{array}{l}0.004 \\
(0.003)\end{array}$ & $\begin{array}{l}0.004^{*} \\
(0.002)\end{array}$ & & & \\
\hline R\&D Pool_D_I2RE & & & & $\begin{array}{l}0.0002 \\
(0.003)\end{array}$ & $\begin{array}{l}0.004^{*} \\
(0.002)\end{array}$ & $\begin{array}{l}0.004^{*} \\
(0.003)\end{array}$ \\
\hline $\ln (\mathrm{R} \& \mathrm{D})$ & $\begin{array}{l}0.292^{* * *} \\
(0.076)\end{array}$ & $\begin{array}{l}0.269^{* * *} \\
(0.078)\end{array}$ & $\begin{array}{l}0.272^{* * *} \\
(0.078)\end{array}$ & $\begin{array}{l}0.286^{* * *} \\
(0.079)\end{array}$ & $\begin{array}{l}0.272^{* * *} \\
(0.078)\end{array}$ & $\begin{array}{l}0.274^{* * *} \\
(0.078)\end{array}$ \\
\hline $\ln (\mathrm{GDP})$ & $\begin{array}{l}0.785^{* * *} \\
(0.123)\end{array}$ & $\begin{array}{l}0.782^{* * *} \\
(0.120)\end{array}$ & $\begin{array}{l}0.784^{* * *} \\
(0.121)\end{array}$ & $\begin{array}{l}0.785^{* * *} \\
(0.123)\end{array}$ & $\begin{array}{l}0.778^{* * *} \\
(0.120)\end{array}$ & $\begin{array}{l}0.783^{\text {*** }} \\
(0.121)\end{array}$ \\
\hline $\ln ($ GDP per capita $)$ & $\begin{array}{l}0.516^{*} \\
(0.303)\end{array}$ & $\begin{array}{l}0.447 \\
(0.294)\end{array}$ & $\begin{array}{l}0.476^{*} \\
(0.290)\end{array}$ & $\begin{array}{l}0.500^{*} \\
(0.301)\end{array}$ & $\begin{array}{l}0.454 \\
(0.291)\end{array}$ & $\begin{array}{l}0.493^{*} \\
(0.291)\end{array}$ \\
\hline $\ln$ (Researchers) & $\begin{array}{l}0.570^{* * *} \\
(0.122)\end{array}$ & $\begin{array}{l}0.593^{* * *} \\
(0.115)\end{array}$ & $\begin{array}{l}0.585^{* * *} \\
(0.113)\end{array}$ & $\begin{array}{l}0.575^{* * *} \\
(0.123)\end{array}$ & $\begin{array}{l}0.587^{* * *} \\
(0.111)\end{array}$ & $\begin{array}{l}0.580^{* * *} \\
(0.113)\end{array}$ \\
\hline $\ln ($ Patent protection $)$ & $\begin{array}{l}3.445^{\text {*** }} \\
(1.265)\end{array}$ & $\begin{array}{l}3.645^{* * *} \\
(1.280)\end{array}$ & $\begin{array}{l}3.508^{\text {**** }} \\
(1.266)\end{array}$ & $\begin{array}{l}3.506^{* * *} \\
(1.265)\end{array}$ & $\begin{array}{l}3.593^{* * *} \\
(1.266)\end{array}$ & $\begin{array}{l}3.443^{* * *} \\
(1.271)\end{array}$ \\
\hline Industry dummies (8) & yes & yes & yes & yes & yes & yes \\
\hline Observations & 201 & 201 & 201 & 201 & 201 & 201 \\
\hline
\end{tabular}

Country-clustered standard errors in parentheses

*** $\mathrm{p}<0.01, * * \mathrm{p}<0.05, * \mathrm{p}<0.1$

In particular, we find that spillovers increase with the intensity of supply chain linkages. As shown in Figure 2, this means that knowledge spillovers are less localized when supply chains are strong. The figure shows our estimates of the effect of a $10 \%$ increase in foreign R\&D by distance and by the level of supply chain intensity. Our results confirm that knowledge spillovers are localized - in the sense that the productivity of foreign R\&D declines with the geographical distance between countries. However, we also find that absolute spillovers increase with the intensity of supply chains links. For example, the average effect of doubling R\&D spending in countries at $300 \mathrm{~km}$ distance with abovemedian I2REP links is an increase in the number of patents by $0.018 \%$. When the R\&D spending is done in a country with I2REP intensity above 90th percentile the increase doubles to $0.042 \%$. Since supply chains have become more extensive in the recent decades, this result shows that they may indeed be an explanation for the evidence that knowledge spillovers have become less localized over time. 


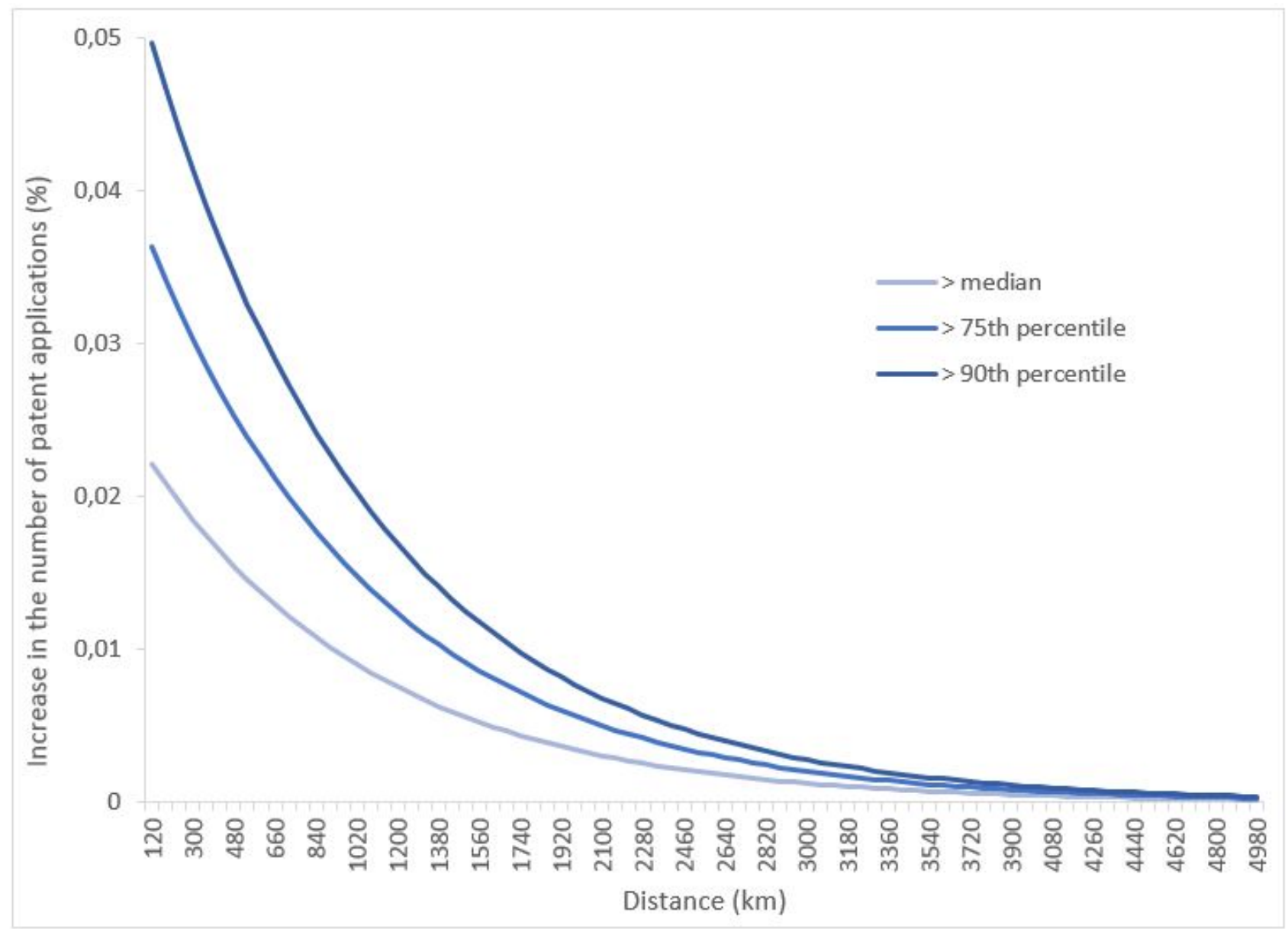

Figure 2: R\&D spillovers by distance and the intensity of supply chain linkages (The effect of a $10 \%$ increase in foreign R\&D spending)

\section{Identification}

A potential problem with our estimations of the spillover effects is identification. We believe that our analysis goes already some way in addressing this problem. First, our estimations of knowledge spillovers for progressively narrower measures of supply chain linkages (Table 3 ) show a ranking of the magnitude of coefficients in line with expectations; that is, larger and more precise coefficients for more intense supply chain linkages. There is no reason why endogenously biased coefficients would show this pattern. This is a strong indication that our results are not driven by endogeneity. Furthermore, our regressions for knowledge spillovers from G5 economies to other economies (Table 6) partially addresses the so called "reflection problem" discussed by Manski (1993). The issue arises in the case of a common shock (for example, if new technology opportunities arise in a certain sector). In this case, firms in all countries will invest more in $R \& D$ in that sector and, at the same time, will be more likely to innovate.

Hereafter, we address the potential endogeneity problem in two additional ways: using panel data and IV regressions. First, we run a panel regression rather than the cross-section analysis for the subsample of economies for which we have complete yearly data on sectoral R\&D expenditure for the period 2000-2008. Data on industry-level R\&D for all years are available only for a restricted subsample. Thus the following estimation is based on data for 16 economies (Australia, Belgium, Chinese Taipei, Czech Republic, France, Germany, Hungary, Japan, Italy, Korea, Mexico, Portugal, Slovenia, Spain, the United Kingdom and the United States). ${ }^{25}$ To this purpose, we estimate a

\footnotetext{
${ }^{25} \mathrm{~A}$ subsample for which less than ten values of R\&D expenditures at the ISIC 2-digit aggregation were missing over the period 2000-2008. The missing values were imputed using the more complete data on total R\&D expenditures in manufacturing. We computed the average ratio of an industry R\&D in total manufacturing R\&D for the years where
} 
dynamic panel model based on Bloom et al. (2013):

(7) Patents $_{i k t}=\exp \left(\alpha+\beta \ln (R \& D \text { Stock })_{i k t-1}+\gamma R \& D\right.$ Pool $_{i k t-1}+\delta \ln \left(\right.$ Patents $\left._{i k t-1}+\iota \tau+\kappa \tau\right)+\epsilon_{i k t}$.

We allow innovation to depend on the past innovative performance and the past stock of $R \& D$ investment from both domestic and foreign industries. We include industry-year and country-year dummies to control for time varying country- and industry-specific factors that impact innovation. Our time span is relatively short so we cannot ignore the dynamic panel bias resulting from inclusion of time-invariant fixed effects. We follow the methodology of Bloom et al. (2013) and include the average of patent applications in the pre-sample period 1995-1999 to control for initial conditions of each country-industry. Both the domestic $R \& D$ and the foreign $R \& D$ pool are lagged so that we alleviate a potential reverse causality problem between R\&D investment and innovation.

In Table 8 we report the results from a specification in which the foreign $R \& D$ pool is defined as the R\&D expenditures from the three far most innovative and R\&D intensive economies (Germany, Japan and the United States). We test how this foreign pool affects the innovative activity of the remaining thirteen economies. ${ }^{26}$ The four measures of foreign $R \& D$ pool now appear all statistically significant and with similar magnitudes (except I2E) but the precision of the estimates retains the same ordering as in our baseline specification - broader measures of supply chains trade result in less precisely estimated coefficients.

Table 8: Dynamic panel regressions

\begin{tabular}{|c|c|c|c|c|}
\hline Dependent: Patents & (1) & (2) & (3) & (4) \\
\hline $\mathrm{R} \& \mathrm{D}$ pool_I2REP $\mathrm{R}_{t-1}$ & $\begin{array}{l}0.0075^{* * *} \\
(0.0020)\end{array}$ & & & \\
\hline $\mathrm{R} \& \mathrm{D}$ pool_I2RE $\mathrm{R}_{t-1}$ & & $\begin{array}{l}0.0078^{* * *} \\
(0.0023)\end{array}$ & & \\
\hline $\mathrm{R} \& \mathrm{D}$ pool_I2 $\mathrm{E}_{t-1}$ & & & $\begin{array}{l}0.0047^{* *} \\
(0.0019)\end{array}$ & \\
\hline $\mathrm{R} \& \mathrm{D}$ pool_I $2 \mathrm{P}_{t-1}$ & & & & $\begin{array}{l}0.0084^{* *} \\
(0.0037)\end{array}$ \\
\hline $\ln (\mathrm{R} \& \mathrm{D} \text { stock })_{t-1}$ & $\begin{array}{l}0.0189^{*} \\
(0.0108)\end{array}$ & $\begin{array}{l}0.0195^{*} \\
(0.0100)\end{array}$ & $\begin{array}{l}0.0226^{* *} \\
(0.0114)\end{array}$ & $\begin{array}{l}0.0223^{* *} \\
(0.0106)\end{array}$ \\
\hline $\ln (\text { Patents })_{t-1}$ & $\begin{array}{l}0.778^{* * *} \\
(0.047)\end{array}$ & $\begin{array}{l}0.785^{* * *} \\
(0.048)\end{array}$ & $\begin{array}{l}0.794^{* * *} \\
(0.049)\end{array}$ & $\begin{array}{l}0.788^{* * *} \\
(0.048)\end{array}$ \\
\hline Pre-sample fixed effects & $\begin{array}{l}0.137^{* * *} \\
(0.049)\end{array}$ & $\begin{array}{l}0.136^{* * *} \\
(0.048)\end{array}$ & $\begin{array}{l}0.136^{* * *} \\
(0.045)\end{array}$ & $\begin{array}{l}0.141^{* * *} \\
(0.044)\end{array}$ \\
\hline Country-year dummies & yes & yes & yes & yes \\
\hline Industry-year dummies & yes & yes & yes & yes \\
\hline Observations & 664 & 664 & 664 & 664 \\
\hline
\end{tabular}

Country-clustered standard errors in parentheses

$* * * \mathrm{p}<0.01,{ }^{* *} \mathrm{p}<0.05, * \mathrm{p}<0.1$

Notes: The subsample of 13 economies includes Australia, Belgium, Chinese

Taipei, Czech Republic, France, Hungary, Italy, Korea, Mexico, Portugal,

Slovenia, Spain and the United Kingdom.

industry-level data were available and used this ratio to fill in missing industry-level values where total manufacturing data were available.

${ }^{26}$ Similar results are obtained when the sourcing economies are G5. 
Second, we use an instrumental variable approach. Maskus et al. (2012) have shown that one important determinant of industry's $R \& D$ intensity is the extent to which firms are able to finance their R\&D expenditures. In less financially developed countries, the industries that are more dependent on external financing have lower R\&D intensity. Therefore, as an instrument for foreign R\&D expenditure, we use the interaction between the industry's dependence on external financing and the degree of the foreign country's financial sector development. Concretely, we use the measure of external financial dependence from Braun (2003), defined as the industry-level median (across firms) of the ratio of capital expenditures minus cash flow from operations divided by capital expenditures. The foreign country's financial development is proxied by the private credit by deposit money banks as \% of GDP, taken from the World Bank's Financial Structure Database 2007.

Following Bloom et al. (2013) we use the control function to implement the instrumental variable approach in a non-linear model setting. In particular, we include the residuals from the linear first stage in the non-linear second stage and base our inference on bootstrapped standard errors. ${ }^{27}$ As a robustness check we also report results from a standard linear IV approach.

Table 9 shows the results of the IV regressions. The first column reports the non-linear IV estimates obtained from our baseline specification - cross-section averages for 29 economies and therefore compares to column (6) of Table 3. The third column reports the non-linear IV results from the same dynamic panel specification as in column (1) of Table 8. For both specifications the size of the coefficients from IV regressions is very similar to the previous estimates, only estimated less efficiently. Furthermore, for both specifications the linear IV estimates (columns (2) and (4)) are in the same range as the non-linear IV estimates. Overall, the results suggest that endogeneity does not drive our results.

Table 9: IV regressions

\begin{tabular}{|c|c|c|c|c|}
\hline Dependent: Patents & $\begin{array}{l}\text { Cross-sec } \\
\text { NegBin } \\
(1)\end{array}$ & $\begin{array}{l}\text { on averages } \\
\text { Linear } \\
(2)\end{array}$ & $\begin{array}{l}\text { Dynamic } \\
\text { NegBin } \\
(3)\end{array}$ & $\begin{array}{l}\text { Linel } \\
\text { Linear } \\
(4)\end{array}$ \\
\hline R\&D pool_I2REP & $\begin{array}{l}0.0043^{*} \\
(0.0023)\end{array}$ & $\begin{array}{l}0.0034^{*} \\
(0.0018)\end{array}$ & $\begin{array}{l}0.0080^{* *} \\
(0.0032)\end{array}$ & $\begin{array}{l}0.0105^{* *} \\
(0.0049)\end{array}$ \\
\hline $\ln (\mathrm{R} \& \mathrm{D})$ & $\begin{array}{l}0.124^{* * *} \\
(0.048)\end{array}$ & $\begin{array}{l}0.091^{* *} \\
(0.042)\end{array}$ & & \\
\hline $\ln (\mathrm{R} \& \mathrm{D} \text { stock })_{t-1}$ & & & $\begin{array}{l}0.008 \\
(0.010)\end{array}$ & $\begin{array}{l}0.008 \\
(0.008)\end{array}$ \\
\hline Country-year dummies & yes & yes & yes & yes \\
\hline Industry-year dummies & yes & yes & yes & yes \\
\hline First Stage F-statistic & 327.66 & 378.47 & 1092.90 & 421.86 \\
\hline Observations & 225 & 225 & 744 & 744 \\
\hline
\end{tabular}

Bootstrapped standard errors in parentheses in (1) and (3).

Country-clustered standard errors in parentheses in (2) and (4).

$* * * \mathrm{p}<0.01,{ }^{* *} \mathrm{p}<0.05,{ }^{*} \mathrm{p}<0.1$

Notes: The dependent variable is $\ln$ (Patents) in columns (2) and (4). The

R\&D pool in columns (3) and (4) is lagged by one year and the regressions include also $\ln (\text { Patents })_{t-1}$ and the pre-sample average number of patents. The First stage F-statistic in columns (2) and (4) is the weak identification Kleibergen-Paap rk Wald F-statistic.

\footnotetext{
${ }^{27}$ In Table 9 we report results from regressions where the residual enters linearly. Our conclusions do not change when we include polynomials of second, third, fourth or fifth degree.
} 


\section{Conclusion}

Our paper investigates how international production networks affect the diffusion of knowledge in a sample of 29 economies. The evidence suggests that production networks are an important driver of technology transfers. In fact, the productivity effect of foreign R\&D spending increases with the intensity of production network links between the sender and the recipient country. Importantly, our results suggest that knowledge spillovers occur only when a country is fully integrated in a GVC network. Mere imports of inputs or exports-platform type of GVC participation does not seem to facilitate knowledge spillovers. Finally, knowledge spillovers within production networks appear to be less spatially localized than the average.

Our findings have important implications. First, the fact that the scope of knowledge spillovers is determined by the structure of the production network can be one reason why the degree of localization of knowledge spillovers has decreased between the periods 1973-83 and 1986-95 (Keller, 2002b) - a period characterized by a strong development of international supply chains.

Second, our finding can also help to explain the emergence of economies such as China, Singapore and the Republic of Korea as major contributors to the pool of technological innovations since 1985. While previously some of these economies had served as a production platform for developed economies (without a deeper involvement in the production chain), the emergence of the "factory Asia" and the strong development of production networks in the region have increased their capacity to innovate. Our findings show that production networks have not just provided a stronger incentive to innovate, thus increasing the amount of resources spent in R\&D (which we control for), but that they have also increased the flow of foreign R\&D absorbed by these economies.

In general, the scope of knowledge spillovers is crucial to determine income distribution among countries. Economic literature has so far stressed that while global spillovers foster convergence at the level of cities, regions or even countries, local spillovers can lead to convergence clusters and thus permanently different levels of income between groups of countries. Our finding suggests that convergence across countries is likely to occur along the production chain lines. This is clearly an interesting avenue for further research. There are also important policy implications. If spillovers of embodied knowledge occur through certain types of supply chain participation, there is an economic rationale for governments to intervene to foster these connections.

\section{References}

Acharya, R.C. \& Keller, W. (2009). Technology transfer through imports. Canadian Journal of Economics 42(4): 1411-1448.

Baldwin, R. (2012). Trade and industrialisation after globalisation's 2nd unbundling: How building and joining a supply chain are different and why it matters. CEPR Discussion Paper \# 8768.

Baldwin, R. \& Lopez-Gonzalez, J. (2013). Supply-chain trade: A portrait of global patterns and several testable hypotheses. CEPR Discussion Paper \# 9421.

Baldwin, R. \& Venables, A. J. (2013). Spiders and snakes: Offshoring and agglomeration in the global economy. Journal of International Economics, 90(2): 245-254.

Bloom, N., Schankerman, M. \& van Reenen, J. (2013). Identifying Technology Spillovers and Product Market Rivalry. Econometrica, 81(4): 1347-1393.

Bottazzi, L. \& Peri, G. (2002). Innovation and spillovers in regions: Evidence from European Patent Data. IGIER Bocconi University Working Paper \# 215.

Bottazzi, L. \& Peri, G. (2003). Innovation and spillovers in regions: Evidence from European patent data. European Economic Review, 47: 687-710.

Bottazzi, L. \& Peri, G. (2005). The International Dynamics of R\&D and Innovation in the Short and in the Long Run. NBER Working Paper \# 11524. 
Braun, M. (2003). Financial Contractibility and Asset Hardness. Unpublished manuscript. Harvard University.

Cameron, A.C. \& Trivedi, P.K. (1998). Regression Analysis of Count Data. Cambridge, England: Cambridge University Press.

Coe, D. T. \& Helpman, E. (1995). International R\&D spillovers. European Economic Review, 39(5): 859-887.

Coe, D. T., Helpman, E. \& Hoffmaister, A. W. (2009). International R\&D spillovers and institutions. European Economic Review, 53(7): 723-741.

Comin, D., Dmitriev, M. \& Rossi-Hansberg, E. (2013). The Spatial Diffusion of Technology. INET Research Notes \# 27. Institute for New Economic Thinking (INET).

Eaton, J. \& Kortum, S. (1999). International Technology Diffusion: Theory and Measurement. International Economic Review, 40(3): 537-570.

Funk, M. (2001). Trade and International R\&D Spillovers among OECD countries. Southern Economic Journal, 67(3): 725-736.

Goto, A. \& Suzuki, K. (1989). R\&D capital, rate of return on R\&D investment and spillover of R\&D in Japanese manufacturing industries. Review of Economics and Statistics, 71(4): 555-564.

Galasso A. \& Schankerman, M. (2013). Patents and Cumulative Innovation: Causal Evidence from the Courts. CEP Discussion Paper \#CEPDP1205, April.

Görg H. \& Greenway, D. (2004). Much ado about Nothing? Do Domestic Firms Really Benefit from Foreign Direct Investment?. World Bank Research Observer \# 19.

Griliches, Z. (1990). Patent Statistics as Economic Indicators: A Survey. Journal of Economic Literature, 28(4):1661-1707.

Grossman, G.M. \& Helpman, E. (1991). Trade, Knowledge Spillovers, and Growth. European Economic Review, 35(2-3): 517-526.

Grossman, G.M. \& Helpman, E. (1991).Innovation and Growth in the Global Economy. Cambridge, Massachusetts: The MIT Press.

Grossman, G.M. \& Rossi-Hansberg, E. (2012). Task Trade between Similar Countries. Econometrica, 80(2): 593-629.

Hovhannisyan, N. \& Keller, W. (2011). International Business Travel: An Engine of Innovation?. NBER Working Paper \# 17100.

Hummels, D. and Ishii, J. \& Yi, K. M. (2001). The nature and growth of vertical specialization in world trade. Journal of International Economics, 54(1): 75-96.

Iacovone, L., Javorcik, B., Keller, W. \& Tybout, J. R. (2011). Supplier Responses to Wal-Mart's Invasion in Mexico. CEPR Discussion Paper \# 8540.

Jaffe, A.B., Trajtenberg, M. \& Henderson, R. (1993). Geographic Localization of Knowledge Spillovers as Evidenced by Patent Citations. The Quarterly Journal of Economics, 108(3): 577-98.

Javorcik, B. (2004). Does Foreign Direct Investment Increase the Productivity of Domestic Firms? In Search of Spillovers through Backward Linkages. American Economic Review, 94(3): 605-627.

Javorcik, B. \& Spatareanu, M. (2009). Tough Love: Do Czech Suppliers Learn from their Relationships with Multinationals?. Scandinavian Journal of Economics, 111(4): 811-833. 
Kokko, A., Zejan, M. \& Ruben, T. (2001). Trade Regimes and Spillover Effects of FDI: Evidence from Uruguay. Weltwirtschaftliches Archiv Bd. 137, 1: 124-149.

Keller, W. (1998). Are international R\&D spillovers trade-related?: Analyzing spillovers among randomly matched trade partners. European Economic Review, 42(8): 1469-1481.

Keller, W. (2000). Do Trade Patterns and Technology Flows Affect Productivity Growth?. World Bank Economic Review, 14(1): 17-47.

Keller, W. (2002a). Trade and the Transmission of Technology. Journal of Economic Growth, 7: 5-24.

Keller, W. (2002b). Geographic localization of international technology diffusion. American Economic Review, 92: 120-142.

Keller, W. (2004). International Technology Diffusion. Journal of Economic Literature, 42(3): 752-782.

Keller, W. (2010). International Trade, Foreign Direct Investment and Technology Spillovers. In B. Hall \& N. Rosenmerg (Eds.), Handbook of the Economics of Innovation. Elsevier North Holland Pubblishers.

Keller, W. \& Yeaple, S. R. (2009). Multinational Enterprises, International Trade, and Productivity Growth: Firm-Level Evidence from the United States. The Review of Economics and Statistics, 91(4): 821-831.

Lichtenberg, F. R. \&. Pottelsberghe de la Potterie, B. (1998). International R\&D spillovers: A comment. European Economic Review, 42(8): 1483-1491.

Lichtenberg, F. R. \&. Pottelsberghe de la Potterie, B. (2001). Does Foreign Direct Investment Transfer Technology across Borders?. The Review of Economics and Statistics, 83(3): 490-497.

Lipsey R. \& Sjoholm, F. (2005). The impact of Inward FDI on Host Countries: Why so different Answers?. In T. Moran, E. Graham \& M. Blomstrom (Eds.), Does FDI Promote Development?. Washington: Institute for International Economics.

Lybbert, T. \& Zolas, N. (2012). Getting Patents and Economic Data to Speak to Each Other: An 'Algorithmic Links with Probabilities' Approach for Joint Analyses of Patenting and Economic Activity. WIPO Economics \& Statistics Series Working Paper \#5, October.

Madsen, J. B. (2005). Technology Spillovers through Trade and TFP Convergence: 120 Years of Evidence for the OECD Countries. EPRU Working Paper Series 05-01, Economic Policy Research Unit (EPRU), University of Copenhagen.

Madsen, J. B. (2009). Trade Barriers, Openness, and Economic Growth. Southern Economic Journal, 76(2): $397-418$.

Manski, C.F. (1993). Identification of Endogenous Social Effects: The Reflection Problem. Review of Economic Studies, 60(3): 531-42.

Maskus, K.E., Neumann, R. \& Seidel, T. (2012). How National and International Financial Development Affect Industrial R\&D. European Economic Review, 56: 72-83.

Nishioka, S. \& Ripoll, M. (2012). Productivity, Trade and the R\&D Content of Intermediate Inputs. European Economic Review, 56(2012): 1573-1592.

OECD (2009). OECD Patent Statistics Manual. Paris: OECD

Park, W. B. (2008). International Patent Protection: 1960-2005. Research Policy, 37: 761-766.

Pisano, G.P \& Shih, W.C. (2012). Producing Prosperity: Why America Needs a Manufacturing Renaissance. Boston, Massachusetts: Harvard Business School Publishing. 
Romer, P.M. (1990). Endogenous technological change. Journal of Political Economy, 98(5): 71-102.

Timmer, M. [editor] (2012). The World Input-Output database (WIOD): Contents, Sources and Methods. WIOD.

http://www.wiod.org/publications/source_docs/WIOD_sources.pdf

Tirole, J. (1988). The Theory of Industrial Organization. Cambridge, Massachusetts: The MIT Press.

World Trade Report (2014, forthcoming). Geneva: World Trade Organization. 